\title{
Determinan Pertumbuhan Laba Perusahaan Manufaktur Di Bursa Efek Indonesia
}

\author{
Rinzany Megasari AWS ${ }^{1}$, Surtikanti ${ }^{2}$, Darmansyah ${ }^{3}$ \\ ${ }^{1.2}$ Universitas Pancasila, Jl. Srengseng Sawah, Jagakarsa, Jakarta Selatan, 12640 \\ ${ }^{3}$ Universitas Komputer Bandung, Jl. Dipati No. 112-116, Lebakgede, Coblong, Bandung 40132
}

INFO ARTIKEL

JEL Classsification:

M41

043

Keywords:

current ratio (cr), debt

to equity ratio (der),

total asset turnover

(tat), net profit margin

(npm) and profit

growth

\section{ABSTRACT}

Profit growth is a ratio that indicates a companys ability to increase net income over the previous year. The higher the profit growth ratio, the better the financial performance of an enterprise. This study aims to examine the influence of current ratio, debt to asset ratio, total asset turnover, and net profit margin on profit growth of consumer goods manufacturing sector in Indonesia Stock Exchange Year 2011-2015. The sample technique used in this research is purposive sampling. There are 21 companies used during the research. The analysis technique used in this research is panel data regression analysis using EViews 10. The sample data is tested by using hypothesis test done by using $R^{2}$, $F$ test, and T test.The results of this study indicate that partially current ratio (CR), and debt to asset ratio (DER) have significant and negative effect, Total Asset Turnover (TAT) has a significant positive effect while Net Profit Margin (NPM) has no significant and positive effect on profit growth Manufacturing of industrial goods sector in Indonesia Stock Exchange Year 2011-2015.

\begin{abstract}
ABSTRAK
Pertumbuhan laba adalah rasio yang menunjukkan kemampuan perusahaan meningkatkan laba bersih dibanding tahun sebelumnya. Semakin tinggi rasio pertumbuhan laba, semakin baik kinerja keuangan suatu perusahaan. Penelitian ini bertujuan untuk menguji pengaruh dari current ratio, debt to asset ratio, total asset turnover, dan net profit margin terhadap pertumbuhan laba perusahaan manufaktur sektor barang konsumsi di Bursa Efek Indonesia Tahun 2011-2015. Teknik sampel yang digunakan dalam penelitian ini adalah purposive sampling. Ada 21 perusahaan yang digunakan selama penelitian. Teknik analisis yang digunakan dalam penelitian ini adalah analisis regresi data panel dengan menggunakan EViews 10. Sampel data diuji dengan menggunakan uji hipotesis dilakukan dengan menggunakan $\mathrm{R}^{2}$, uji $\mathrm{F}$, dan uji T. Hasil penelitian ini menunjukkan bahwa secara parsial current ratio (CR), dan debt to asset ratio (DER) berpengaruh signifikan dan negatif, Total Asset Turnover (TAT) berpengaruh signifikan positif sedangkan Net Profit Margin (NPM) tidak berpengaruh signifikan dan positif terhadap pertumbuhan laba manufaktur sektor barang industri di Bursa Efek Indonesia Tahun 2011-2015.
\end{abstract}

*Email Korespondensi: 'egha_rinzani@yahoo.co.id 


\section{Pendahuluan}

Perkembangan industri di Indonesia membuat setiap perusahaan yang ada bersaing untuk memajukan perusahaan. Setiap perusahaan mempunyai tujuan utama yaitu untuk memakmurkan pemilik perusahaan. Hal paling mendasar yang dilihat dari suatu laporan keuangan perusahaan adalah pada aspek informasi laba. Menurut Statement of Financial Accounting Concept (SFAC) No 1. Informasi laba merupakan perhatian utama untuk menaksir kinerja atau mempertanggungjawabkan dari manajer sebagai wakil dari principal. Selain itu informasi laba juga membantu pemilik atau pihak lain dalam menaksir earnings power perusahaan dimana informasi laba merupakan komponen yang sangat penting sebagai sinyal kinerja suatu perusahaan dan berguna sebagai dasar pembuatan berbagai keputusan penting oleh pengguna informasi. Tidak dapat dipungkiri bahwa pertumbuhan laba tidak bisa terlepas dari kinerja keuangan perusahaan. Untuk dapat memenuhi kualifikasi informasi yang berguna menetapkan empat karakteristik kualitatif pokok, yaitu dapat dipahami, relevan, keandalan, dan dapat diperbandingkan (Ikatan Akuntan Indonesia, 2002).

Menurut Cahyaningrum (2012) Analisis laporan keuangan yang dilakukan dapat berupa perhitungan dan interprestasi melalui rasio keuangan. Jika rasio keuangan dapat dijadikan sebagai prediktor pertumbuhan laba di masa yang akan datang, temuan ini merupakan pengetahuan yang cukup berguna bagi para pemakai laporan keuangan yang secara riil, maupun potensial berkepentingan dengan suatu perusahaan. Rasio keuangan diperoleh dari perbandingan angkaangka yang ada dalam laporan keuangan. Secara umum, rasio keuangan dapat dikelompokkan menjadi rasio likuiditas, rasio leverage, rasio aktivitas dan rasio profitabilitas (Kasmir, 2014).

Berikut Fenomena yang terjadi pada salah satu perusahaan manufaktur sektor industri barang konsumsi di Bursa Efek Indonesia. Fenomena tersebut seperti yang terlihat pada tabel dibawah ini:

Tabel 1. PT. Unilever Tbk Periode 2014-2015

\begin{tabular}{ccccc}
\hline Periode & Laba Bersih & Penjualan & Aset & Hutang \\
\hline 2014 & 5.93 Triliun & 34.51 Triliun & 14.28 Triliun & 9.53 Triliun \\
2015 & 5.85 Triliun & 36.48 Triliun & 15.73 Triliun & 10.90 Triliun \\
Persentase (\%) & $1.36 \%$ & $5.71 \%$ & $10.15 \%$ & $14.38 \%$ \\
\hline
\end{tabular}

Sumber : Britama.com, 2016

PT Unilever Indonesia Tbk (UNVR) melaporkan penurunan kinerja pada tahun 2015 sebesar $1,36 \%$ dengan laba bersih pada tahun 2015 mencapai Rp. 5,85 triliun dibandingkan Rp. 5,93 triliun pada tahun 2014. Meskipun kinerja Perseroan menurun, Penjualan Perseroan tetap mengalami kenaikan yang cukup besar di tahun 2015 yaitu sebesar Rp. 1,97 triliun atau naik 5,71 \% menjadi Rp. 36,48 triliun dari Penjualan tahun 2014 yaitu Rp. 34,51 triliun. Hingga akhir tahun 2015, Total aset PT. Unilever Indonesia Tbk
(UNVR) mencapai Rp. 15,73 triliun, naik sebesar 10,15 \% dari Total aset tahun 2014 yaitu Rp. 14,28 triliun, sedangkan hutang mencapai Rp. 10,90 triliun di tahun 2015, mengalami kenaikan sebesar 14,38 \% dari hutang tahun 2014 yaitu Rp. 9,53 triliun. Penurunan pertumbuhan laba disebabkan kondisi perekonomian di Indonesia mengalami keterpurukan akibat krisis moneter, krisis global dan kenaikan dolar sehingga pertumbuhan laba perusahaan manufaktur justru banyak yang mengalami penurunan. 
Fenomena lain yang terjadi pada perusahaan manufaktur di Bursa Efek Indonesia periode
2011 sampai dengan 2015. Fenomena tersebut sebagai berikut:

Tabel 2. Rasio pada Perusahaan Manufaktur yang

Terdaftar di Bursa Efek Indonesia Periode 2011-2015

\begin{tabular}{cccccc}
\hline Rasio & $\mathbf{2 0 1 1}$ & $\mathbf{2 0 1 2}$ & $\mathbf{2 0 1 3}$ & $\mathbf{2 0 1 4}$ & $\mathbf{2 0 1 5}$ \\
\hline Pertumbuhan Laba & 0.20 & 0.36 & 0.10 & 0.02 & $(0.08)$ \\
CR & 2.89 & 3.00 & 2.60 & 2.15 & 3.22 \\
DER & 2.15 & 1.63 & 1.55 & 0.19 & 0.32 \\
TAT & 1.42 & 1.39 & 1.37 & 1.41 & 1.22 \\
NPM & 0.13 & 0.14 & 0.14 & 0.10 & 0.09 \\
\hline
\end{tabular}

Sumber: Indonesian Capital Market Directory (ICMD) yang telah diolah

Penelitian mengenai Current Ratio (CR), Debt to Equity Ratio (DER), Total Asset Turnover (TAT), Net Profit Margin (NPM) telah banyak dilakukan. Penelitian terdahulu ada yang menunjukkan berpengaruh dan tidak berpengaruh terhadap pertumbuhan laba. Pada penelitian yang dilakukan Wijaya (2012), dan Grisely (2015) menunjukkan bahwa Current Ratio (CR) berpengaruh terhadap pertumbuhan laba, sedangkan pada penelitian yang dilakukan Rizkiyah (2010), Gunawan dan Wahyuni (2014) menunjukkan bahwa Current Ratio (CR) tidak berpengaruh terhadap pertumbuhan laba.

Pada penelitian yang dilakukan Zakaria, dkk (2015) menunjukkan bahwa Debt to Equity Ratio (DER) berpengaruh positifterhadapPertumbuhan Laba, sedangkan pada penelitian yang dilakukan Cahyaningrum (2012), Gunawan dan Wahyuni (2014), VZanora (2013) menunjukkan bahwa Debt to Equity Ratio (DER) tidak berpengaruh terhadap Pertumbuhan Laba. Pada penelitian yang dilakukan Hapsari (2007), Cahyaningrum (2012), Wijaya (2012), Gunawan dan Wahyuni (2014), Grisely (2015) menunjukkan bahwa Total Asset Turnover (TAT) berpengaruh terhadap pertumbuhan laba. Sedangkan pada penelitian yang dilakukan Rizkiyah (2010), Taruh (2012) dan Adisetiawan (2012) menunjukkan bahwa Total Asset Turnover (TAT) tidak berpengaruh terhadap pertumbuhan laba. Pada penelitian yang dilakukan Cahyaningrum (2012), Wijaya (2012), Adisetiawan (2012), Prasetyo, Darminto dan Nuzula (2016) menunjukkan bahwa Net Profit Margin (NPM) berpengaruh terhadap pertumbuhan laba. Sedangkan pada penelitian yang dilakukan Rizkiyah (2010) menunjukkan bahwa Net Profit Margin (NPM) tidak berpengaruh terhadap pertumbuhan laba.

Berdasarkan fenomena yang ada dan perbedaan antar penelitian-penelitian terdahulu (research gap), pada kenyataannya tidak semua rasio keuangan Current Ratio (CR), Debt to Equity Ratio (DER), Total Asset Turnover (TAT), Net Profit Margin (NPM) berpengaruh terhadap pertumbuhan laba suatu perusahaan. Penelitian ini dimaksudkan untuk melakukan penelitian kembali temuan-temuan empiris mengenai rasio keuangan CR, DER, TAT, NPM terhadap pertumbuhan laba pada perusahaan manufaktur yang terdaftar di Bursa Efek Indonesia (BEI) pada periode 2011 sampai dengan 2015. Berdasarkan latar belakang tersebut peneliti tertarik untuk melakukan penelitian dengan judul: "Determinan Pertumbuhan Laba Perusahaan Manufaktur di Bursa Efek Indonesia"

\section{Telaah Teori dan Pengembangan Hipotesis}

Signalling theory mengemukakan bagaimana seharusnya perusahaan memberikan signal pada pengguna laporan keuangan. Brigham dan Houston (2004: 40) menyatakan bahwa sinyal adalah suatu tindakan yang diambil oleh manajemen perusahaan yang 
memberikan petunjuk bagi investor tentang bagaimana manajemen memandang prospek perusahaan. Perusahaan dengan prospek yang menguntungkan apabila laba yang dilaporkan oleh perusahaan meningkat maka informasi tersebut dapat dikategorikan sebagai sinyal baik karena mengindikasikan kondisi perusahaan yang baik. Sebaliknya apabila laba yang dilaporkan menurun maka perusahaan berada dalam kondisi tidak baik sehingga dianggap sebagai sinyal yang jelek.

Stakeholder theory menyatakan bahwa perusahaan bukanlah entitas yang hanya beroperasi untuk kepentingannya sendiri, namun harus memberikan manfaat bagi stakeholdernya yaitu pemegang saham, kreditor, konsumen, supplier, pemerintah, masyarakat, analis dan pihak lain (Ghazali dan Chariri, 2007). Kelompok stakeholder inilah yang menjadi bahan pertimbangan bagi manajemen perusahaan dalam mengungkap atau tidak suatu informasi di dalam laporan perusahaan tersebut. Tujuan utama dari teori stakeholder adalah untuk membantu manajemen perusahaan dalam meningkatkan penciptaan nilai sebagai dampak dari aktivitas-aktivitas yang dilakukan dan meminimalkan kerugian yang mungkin muncul bagi stakeholder.

Current ratio merupakan rasio likuiditas (Liquidity Ratio) menggambarkan kemampuan perusahaan memenuhi kewajiban jangka pendeknya yang telah jatuh tempo. Current ratio sendiri merupakan salah satu indikator dari rasio likuiditas. Current ratio merupakan rasio antara aktiva lancar dengan hutang lancar yang dimiliki oleh perusahaan. Rasio ini mengukur aktiva yang dimiliki perusahaan dalam hutang lancar perusahaan (Husnan, 1994).

Menurut Riyanto (2001) Debt to Equity Ratio merupakan besarnya proporsi antara total debt (total hutang) dengan total shareholder's equity (total modal sendiri). Total debt merupakan total liabilities (baik utang jangka pendek maupun jangka panjang), sedangkan total shaareholder's equity merupakan total modal sendiri (total modal saham yang di setor dan laba yang ditahan) yang dimiliki perusahaan.

Total Assets Turnover digunakan untuk mengukur sampai seberapa besar efektivitas perusahaan dalam menggunakan sumber dayanya yang berupa asset. Semakin tinggi rasio ini semakin efisien penggunaan asset dan semakin cepat pengembalian dana dalam bentuk kas (Halim, 2007). Total Assets Turnover sendiri merupakan rasio antara penjualan dengan total aktiva yang mengukur efisiensi penggunaan aktiva secara keseluruhan. Apabila rasio rendah itu merupakan indikasi bahwa perusahaan tidak beroperasi pada volume yang memadai bagi kapasitas investasinya (Kasmir, 2014). Sedangkan menurut Weston dan Brigham (1989) TAT merupakan rasio pongelolaan aktiva terakhir, mengukur perputaran atau pemanfaatan dari semua aktiva perusahaan. Apabila perusahaan tidak menghasilkan volume usaha yang cukup untuk ukuran investasi sebesar total aktivanya, penjualan harus ditingkatkan.

Rasio Net Profit Margin disebut juga dengan rasio pendapatan terhadap penjualan. Menurut Darsono dan Ashari (2005), Laba bersih dibagi penjualan bersih. Rasio ini menggambarkan besar laba bersih yang diperoleh perusahaan pada setiap penjualan yang dilakukan. Pertumbuhan laba (Harahap, 2011) adalah rasio yang menunjukkan kemampuan perusahaan meningkatkan laba bersih dibanding tahun sebelumnya. Laba bersih (Kasmir, 2008) merupakan laba yang telah dikurangi biayabiaya (beban perusahaan pada suatu periode tertentu) termasuk pajak. Pertumbuhan laba merupakan selisih laba bersih tahun tertentu dengan laba bersih tahun sebelumnya dibagi dengan laba bersih tahun sebelumnya. 


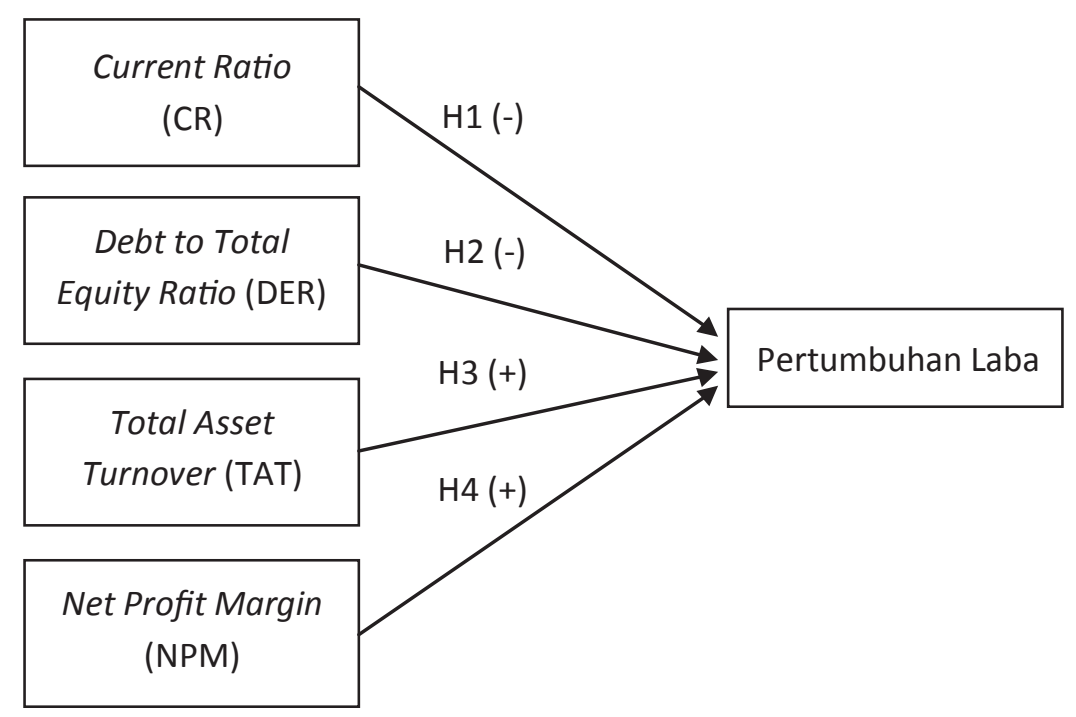

Gambar 1. Kerangka Pemikiran Teoritis

\section{Metode Penelitian}

Sampel penelitian adalah perusahaan manufaktur sektor barang konsumsi. Jumlah sampel diuji sebanyak 105 data tahun. Tahun observasi 2011-2015. Pengujian dilakukan dengan data panel mencakup uji chow untuk memilih model, uji hausman untuk membandingkan hasil pengujian model, dan diakhiri dengan uji $t$ untuk menguji hipotesis. Data panel yang merupakan gabungan antara data deret waktu (time-series) dan data deret lintang (cross section). Pada penelitian ini menggunakan data panel balance panel. Alat pengolahan data dengan menggunakan program Eviews. Menurut Ajija (2011) mengemukakan bahwa keunggulan-keunggulan regresi data panel memiliki implikasi pada tidak harus dilakukan pengujian asumsi klasik dalam model data panel, karena penelitian yang menggunakan data panel memperbolehkan identifikasi parameter tertentu tanpa perlu membuat asumsi yang ketat atau tidak mengharuskan terpenuhinya semua asumsi klasik regresi linier seperti pada ordinary least square (OLS).

\section{Hasil dan Pembahasan}

Uji Chow ini bertujuan untuk memilih model apakah yang akan digunakan antara model fixed effect dan model common effect. Berikut merupakan output dari uji menggunakan Uji Chow.

Tabel 3. Hasil Uji Chow

\begin{tabular}{lrrr}
\hline Effects Test & Statistic & d.f. & Prob. \\
\hline Cross-section F & 1.552528 & $(20,80)$ & 0.0868 \\
Cross-section Chi-square & 34.435688 & 20 & 0.0233 \\
\hline
\end{tabular}

SumberSumber: Hasil Olah Eviews

Pada perhitungan yang telah dilakukan, dapat dilihat bahwa nilai probability pada test cross-section fixed effects memperlihatkan angka bernilai 0.0233 yang berarti tidak signifikan dengan tingkat signifikansi $95 \%(\alpha=5 \%)$ dan menggunakan distribusi Chi-Squere (Gujarati, 2003). Berdasarkan hasil dari pengujian $U j i$ Chow, maka metode pilihan yang digunakan pada penelitian yaitu Fixed Effect Model. Karena hasil penentuan estimasi model adalah Fixed 
Effect Model (FEM), maka perlu dilakukan uji Hausman untuk menentukan apakah model menggunakan fixed effect model (FEM) atau random effect model (REM).

Hausman test ini bertujuan untuk membadingkan antara Fixed Effect Model (FEM) dan Random Effect Model (REM). Hasil dari pengujian dengan menggunakan tes ini ialah mengetahui metode mana yang sebaiknya dipilih. Pada perhitungan yang telah dilakukan, dapat dilihat bahwa nilai probability pada test cross-section random effects memperlihatkan angka bernilai 0.0010 yang berarti signifikan dengan tingkat signifikansi $95 \%(\alpha=5 \%)$ dan menggunakan distribusi Chi-Square (Gujarati, 2003). Berdasarkan hasil dari pengujian hausman test, maka metode pilihan yang digunakan pada penelitian yaitu Fixed Effect Model.

Tujuan dari penelitian ini digunakan untuk menguji apakah terdapat pengaruh dan untuk menganalisis ada atau tidaknya pengaruh Current Ratio (CR), Debt to Equity Ratio (DER), Total Assets Turnover (TAT), Net Profit Margin (NPM) terhadap pertumbuhan laba dilakukan dengan menggunakan analisis statistik regresi dengan menggunakan program E-Views 10 . Berdasarkan hasil regresi data panel dengan menggunakan metode Generalized Least Squeres (GLS) untuk melihat hubungan diantara variabel dependen dengan variabel independen dapat dibuat kesimpulan atas hasil analisis regresi persamaan sebagaimana dapat dilihat pada tabel berikut.

Tabel 4. Hasil Regresi Data Panel

\begin{tabular}{crrrr}
\hline Variable & Coefficient & Std. Error & t-Statistic & Prob. \\
\hline C & 0.335365 & 0.199521 & 1.680849 & 0.0959 \\
CR & -0.001102 & 0.000373 & -2.953903 & 0.0039 \\
DER & -0.297612 & 0.113781 & -2.615643 & 0.0103 \\
TAT & 0.261584 & 0.090752 & 2.882418 & 0.0048 \\
NPM & 0.006310 & 0.007354 & 0.857940 & 0.3930 \\
R-squared & 0.142704 & & & \\
Adjusted R-squared & 0.108412 & & & \\
S.E. of regression & 0.540121 & & & \\
F-statistic & 4.161456 & & & \\
Prob(F-statistic) & 0.003689 & & & \\
\hline
\end{tabular}

Berdasarkan tabel 4.9 hasil Analisis menunjukkan koefisien determinasi $\left(\mathrm{R}^{2} / R\right.$ square) adalah 0,1472704 . Hal ini berarti $14,73 \%$ variabel pertumbuhan laba dapat dijelaskan oleh variabel Current Ratio (CR), Debt to Equity Ratio (DER), Total Asset Turnover (TAT), Net Profit Margin (NPM) Perusahaan Manufaktur di Bursa Efek Indonesia Tahun 2011-2015. Sisanya $85,27 \%$ dapat dijelaskan oleh variabel-variabel lain yang tidak dimasukkan ke dalam penelitian ini. Variabel lain yang tidak dijelaskan dalam penelitian ini seperti Quick Ratio, Cash Ratio, Total Debt to Total Assets Ratio, Profit Margin, Gross Profit Margin, Return On Investment (ROI), Return On Assets, dll.

Uji keterandalan model atau uji kelayakan model atau disebut sebagai uji $\mathrm{F}$ dilakukan untuk mengidentifikasi model regresi yang diestimasi layak atau tidak. Layak berarti model yang diestimasi layak digunakan untuk menjelaskan pengaruh variabel-variabel bebas terhadap variabel terikat. Ketentuan bahwa model 
dikatakan layak apabila nilai prob. F-stat lebih kecil daripada $\alpha$ : 0,05, sebaliknya jika nilai prob. F-stat lebih besar daripada $\alpha$ : 0,05, maka dapat dikatakan bahwa model regresi yang diestimasi tidak layak.

Berdasarkan hasil uji kelayakan model menggunakan uji $\mathrm{F}$ menunjukkan nilai probabilitas (F-statistic) sebesar 0,003689 lebih kecil daripada 0,05 . Sehingga dapat disimpulkan bahwa estimasi model regresi data panel layak. Artinya model regresi data panel dapat diterima dan terdapat pengaruh signifikan dari empat variabel independen (CR, DER, TAT dan NPM) terhadap pertumbuhan laba.

Nilai probabilitas $\mathrm{t}$-stat untuk variabel Current Ratio (CR) adalah sebesar 0,0039 lebih kecil daripada 0,05 , dan t-stat adalah sebesar $-2,953903$ sehingga keputusan yang diambil adalah menolak Ho dan menerima Ha. Maka kesimpulan yang diambil adalah current ratio (CR) berpengaruh signifikan dan negatif terhadap pertumbuhan laba Perusahaan Manufaktur di Bursa Efek Indonesia Tahun 2011-2015. Nilai probabilitas t-stat untuk variabel Debt to Equity Ratio (DER) adalah sebesar 0,0103 lebih besar daripada 0,05 , dan t-stat adalah sebesar $-2,615643$ sehingga keputusan yang diambil adalah menolak Ho dan menerima Ha, sehingga kesimpulan yang diambil adalah Debt to Equity Ratio (DER) berpengaruh signifikan dan negatif terhadap pertumbuhan laba Perusahaan Manufaktur di Bursa Efek Indonesia Tahun 20112015. Nilai probabilitas t-stat untuk variabel Total Asset Turnover (TAT) adalah sebesar 0,0048 lebih kecil daripada 0,05 , dan t-stat adalah sebesar 2,882418 sehingga keputusan yang diambil adalah menolak Ho dan menerima Ha, Total Asset Turnover (TAT) berpengaruh signifikan dan positif terhadap pertumbuhan laba Perusahaan Manufaktur di Bursa Efek Indonesia Tahun 2011-2015. Nilai probabilitas t-stat untuk variabel Net Profit Margin (NPM) adalah sebesar 0,3930 lebih besar daripada 0,05, dan t-stat adalah sebesar 0,857940 sehingga keputusan yang diambil adalah menerima Ho,
Net Profit Margin (NPM) tidak berpengaruh signifikan dan positif terhadap perubahan laba Perusahaan Manufaktur di Bursa Efek Indonesia Tahun 2011-2015.

\section{Kesimpulan, Keterbatasan, dan Saran}

Dari hasil temuan penelitian, maka dapat diambil kesimpulan bahwa pada hasil regresi pada dua puluh satu perusahaan manufaktur sektor barang konsumsi Current ratio (CR) berpengaruh negatif dan signifikan terhadap pertumbuhan laba Manufaktur di Bursa Efek Indonesia Tahun 2011-2015. Debt to Equity Ratio (DER) berpengaruh negatif dan signifikan terhadap pertumbuhan laba Perusahaan Manufaktur di Bursa Efek Indonesia Tahun 2011-2015.

Total Asset Turnover (TAT) berpengaruh positif dan signifikan terhadap pertumbuhan laba Perusahaan Manufaktur di Bursa Efek Indonesia Tahun 2011-2015. Artinya TAT naik maka pertumbuhan laba juga naik. Net Profit Margin (NPM) berpengaruh positif dan tidak signifikan terhadap pertumbuhan laba Perusahaan Manufaktur di Bursa Efek Indonesia Tahun 2011-2015. Artinya NPM naik maka pertumbuhan laba juga naik.

Penelitian ini hanya terbatas pada menguji beberapa faktor yang dapat mempengaruhi pertumbuhan laba yaitu hanya dilihat dari Current Ratio (CR), Debt to Equity Ratio (DER), Total Assets Turnover (TAT), Net Profit Margin (NPM), padahal masih ada beberapa faktor lainnya yang dapat diuji untuk mempengaruhi pertumbuhan laba seperti Quick Ratio, Cash Ratio, Total Debt to Total Assets Ratio, Profit Margin, Gross Profit Margin, Return On Investment (ROI), Return On Assets, perputaran piutang dan perputaran persediaan.

Penelitian ini hanya terbatas pada perusahaan-perusahaan manufaktur sektor barang konsumsi sehingga generalisasi hasil temuan dan rekomendasi penelitian ini kurang dapat diberlakukan untuk obyek penelitian di seluruh perusahaan manufaktur, sehingga 
perlu dilakukan juga pengujian untuk sampel perusahaan lainnya. Penelitian ini dapat dikembangkan dengan membandingkan pengaruh CR, DER, TAT dan NPM terhadap pertumbuhan laba diperusahaan dan non perusahaan. Bagi penelitian selanjutnya dapat dilakukan dengan menambah variabel lain atau menggunakan variabel lain, Selain itu memperbanyak sampel penelitian agar hasil penelitian selanjutnya menjadi lebih tepat dan akurat.

Perusahaan disarankan untuk lebih memperhatikan dan berhati-hati dalam menggunakan aktiva lancar, hutang lancar, peningkatan produk lebih inovatif serta melakukan promosi agar perusahaan memiliki kualitas yang baik dalam pengolaan dana. Sehingga sumber dana tersebut dapat dialokasikan dengan tepat demi mencapai tujuan perusahaan yaitu meningkatkan laba perusahaan. Laba merupakan salah satu tolak ukur yang biasanya kita lihat dari suatu perusahaan, apakah sukses atau tidaknya perusahaan cenderung dilihat dari bagaimana laba perusahaan tersebut. Para investor harus jeli dalam melihat hal seperti ini, termasuk faktor apa saja yang dapat mempengaruhi pertumbuhan laba dengan menganalisis rasio keuangan dapat memberikan gambaran bagi para calon investor dalam mengambil keputusan untuk investasi.

\section{Daftar Referensi}

Adisetiawan, R. (2012). Analisis Pengaruh Kinerja Keuangan dalam Memprediksi Pertumbuhan Laba. Jurnal Aplikasi Manajemen, 10(3), 669-681.

Ajija, S. R., Sari, D. W., Setianto, R. H., \& Primanti, M. R. (2011). Cara cerdas menguasai Eviews. Jakarta: Salemba Empat.

Bambang, R. (2001). Dasar-dasar pembelanjaan perusahaan. Edisi Keempat, Cetakan Ketujuh, BPFE Yogyakarta, Yogyakarta.

Brigham and Houston, 1989. Dasar Manajemen Keuangan, Buku II. Jakarta: Erlangga
Brigham, Eugene F.dan Joel Houston, 2004. Financial Management, Edisi 10,. Jilid 1, Alih Bahasa Ali Akbar Yulianto. Jakarta: Penerbit Salemba Empat.

Cahyaningrum, Ndaru Hesti, 2012. Analisis Manfaat Rasio Keuangan dalam Memprediksi Pertumbuhan Laba (Studi Kasus : Perusahaan Manufaktur Yang Terdaftar di Bursa Efek Indonesia Periode 2005 sampai dengan 2010). Skripsi. Program Sarjana Fakultas Ekonomika dan Bisnis Universitas Diponegoro Semarang.

Darsono, A. (2005). Pedoman Praktis Memahami Laporan Keuangan. Yogyakarta: Andi.

Ghozali, I., \& Chariri, A. (2007). Teori akuntansi. Semarang: Badan Penerbit Universitas Diponegoro.

Grisely, 2015.Analisis Pengaruh Rasio Keuangan Terhadap Perubahan Laba Pada Perusahaan Wholesale and Retail Trade Yang Terdaftar di Bursa Efek Indonesia (Periode 2009 2012).Skripsi.Faculty of Economics, Riau University, Pekanbaru, Indonesia.

Gujarati, D., \& Porter, D. (2003). Multicollinearity: What happens if the regressors are correlated. Basic econometrics, 363.

Gunawan, A., \& Wahyuni, S. F. (2014). Pengaruh rasio keuangan terhadap pertumbuhan laba pada perusahaan perdagangan di Indonesia. Jurnal Ilmiah Manajemen dan Bisnis, 13(1).

Halim, Abdul, 2007. Akuntansi Sektor Publik Akuntansi Keuangan Daerah, Edisi Revisi. Jakarta: Salemba Empat.

Hapsari, E. A. (2007). Analisis Rasio Keuangan untuk Memprediksi Pertumbuhan Laba (Studi Kasus: Perusahaan Manufaktur yang terdaftar di Bursa Efek Jakarta periode 2001 sampai dengan 2005) (Doctoral dissertation, Program Pascasarjana Universitas Diponegoro).

Harahap, Sofyan Syafri, 2007. Analisis Kritis Atas Laporan Keuangan. Jakarta : Raja. 
Grafindo Persada.

Husnan, Suad, 1994. Dasar-dasar Teori Portofolio, Edisi Kedua. Yogyakarta: Unit Penerbitan dan Percetakan AMP YKPN.

Ikatan Akuntansi Indonesia, 2002. Standar Akuntansi Keuangan. Jakarta: Salemba Empat.

Kasmir, 2014. Analisis Laporan Keuangan, Edisi Pertama, Cetakan Ketujuh. Jakarta: PT. Rajagrafindo Persada.

Prasetyo, R. Y., \& Nuzula, N. F. (2016). Pengaruh Profitabilitas Terhadap Pertumbuhan Perusahaan (Studi pada Perusahaan Properti dan Real Estate yang Terdaftar pada Bursa Efek Indonesia Periode 2011-2013). Jurnal Administrasi Bisnis, 30(1), 135-141.

Rizkiyah, Eny. 2010. Faktor-Faktor yang Mempengaruhi Pertumbuhan Laba pada Perusahaan Otomotif yang Go Publik di Bursa Efek Indonesia. Skripsi. Universitas Pembangunan Nasional "Veteran", Jawa Timur.

Taruh, V. (2012). Analisis Rasio Keuangan Dalam Memprediksi Pertumbuhan
Laba Pada Perusahaan Manufaktur Di BEI. Jurnal Pelangi Ilmu, 5(01).

Wijaya, A. P. W. A. P., \& Wijaya, A. P. (2013). Analisis Rasio Keuangan dalam Merencanakan Pertumbuhan Laba: Perspektif Teori Signal. Kajian Ilmiah Mahasiswa Manajemen, 2(2).

Zakaria, Mohamad Rizki, dkk. 2015. Pengaruh Debt To Asset Ratio (DAR), Debt To Equity (DER), dan Times Interest Earned (TIE) Terhadap Pertumbuhan Laba pada Perusahaan Rokok yang Terdaftar di Bursa Efek Indonesia (BEI). Tesis. Jurusan Akuntansi Universitas Negeri Gorontalo.

Zanora, Verty. 2013. Pengaruh Likuditas, Leverage dan Aktivitas Terhadap Pertumbuhan Laba pada Perusahaan Manufaktur yang Terdaftar di BEI. Skripsi. Departemen Akuntansi Fakultas Ekonomi. Universitas Negeri Padang. 